\title{
Grapple for Equality: A Critical Analysis of Caste and Gender Discrimination in Bama's Vanmam (Vendetta)
}

\author{
J. Rajasree Menon, Ramanathan P V
}

\begin{abstract}
Divisiveness among humans is so inherent, rampant and intuitive that none would find it easy to escape the oppression resulting from this man-made setback. The Human psyche covets to rule, master and exploit its power over others; and this is the core and the most intimate cause of all intolerance and oppression in our world, whatever label one wants to bracket then under, say, caste, creed, race, gender or faith. This paper titled, Grapple for Equality: A Critical Analysis of Caste and Gender Discrimination in Bama's Vanmam (Vendetta) is an attempt to identify the gender inequality and sexual violence among Dalit women exposed by the author. The main themes of the Dalit writings in India usually centre on subjects like social disability, caste system, economic inequality, contemporary cruelties and cultural assertion that have been uniquely entitled 'the struggle for identity'. Bama, one of the renowned Tamil Dalit woman writers, dwells on the themes of caste and gender discrimination in most of her novels. The novel Vanmam mainly focuses on Dalit women, highlighting how they are subjected to social discriminations of multiple sorts.

Key Words: Sexual Violence, Gender Inequality, Cultural Stereotypes, Subaltern Studies
\end{abstract}

\section{INTRODUCTION}

The pattern and working of the caste system in India, and the way it is seen by the artistic eyes of the author, defines the term Dalit as people who are wounded, ruptured, shattered, crushed and destroyed. A Dalit is frequently called an untouchable - a person who comes under a category that defies any kind of definition. Varna is a categorization in the Indian traditional context that dealt with the belief that most of the humans are presumably designed from the various parts of the divine form of the Universal Being (Creator) called The Purusha. But today, Varna has been replaced by the various 'castes' in the social hierarchy which roughly define the social status of a person, and often decides whom they can marry and what profession they can pursue. Dalits fall outside of the Varna system, anyway.

In the Bible, different forms of this term have been used to describe people who have been reduced to nothingness or helplessness. The present usage of the term Dalit goes back to the nineteenth century, when a Marathi social reformer and revolutionary, Mahatma Jyotirao Phule (1826-1890), used it to describe the out-castes and untouchables as the oppressed and the broken victims of our caste-ridden society. Under the

Revised Manuscript Received on October 10, 2019.

* Correspondence Author

J. Rajasree Menon*, research scholar pursuing her Ph.D in the Department of English Amrita Vishwa Vidyapeetham, Amritapuri Campus, Kollam.

Dr. Ramanathan P V, Amrita Vishwa Vidyapeetham

(C) The Authors. Published by Blue Eyes Intelligence Engineering and Sciences Publication (BEIESP). This is an open access article under the CC BY-NC-ND license (http://creativecommons.org/licenses/by-nc-nd/4.0/) charismatic leadership of Dr. B. R. Ambedkar (1891-1956), this term gained greater importance and popularity. During the 1970s, the followers of the Dalit Panther Movement of Maharashtra gave currency to the term 'Dalit' as a constant reminder of their age-old oppression, denoting both their state of deprivation and the people who are oppressed. This term for them is not a mere name or title: for them it has become an expression of hope, the hope of recovering their past self-identity. The term has gained a new connotation with a more positive meaning. It must be remembered that Dalit does not mean caste or low-caste or poor; it refers to the deplorable state or condition to which a large group of people has been reduced by social convention and in which they are now living. [2] (Himanshu Charan Sadangi, 2008)

Bama is the most celebrated Dalit woman writer who has been at the forefront of Dalit activism and she is actively involved in social issues, especially Dalit issues.

\section{SUBALTERN STUDIES}

Dr. B R Ambedkar states, "It is a sin to get birth in a country whose people are so caste ridden and prejudiced." [188] (Ramesh Chandra, 2003). The military term 'subaltern' has attained broader nuances in the Post-Colonial theory which refers to the outlook of people from groups and regions outside hegemonic power. The Routledge Dictionary of Literary Terms defines the term subaltern thus:

'Subaltern' was first deployed as a critical term by the Italian communist Antonio Gramsci...the term refers to the non-elite classes, including but not restricted to the proletariat. ... Considering the 'politics of the people' as consisting of more than just a revolutionary, industrialized working class... [for Gramsci] the rigid frameworks of orthodox Marxism limited any full analysis of class society... [He] placed greater emphasis on the cultural and ideological dimensions of hegemony and subordination. [230] (Peter Childs and Roger Fowler, 2006)

\section{VANMAM (VENDETTA): AN OVERVIEW}

Vanmam (Vendetta) (2002), is the third novel of Bama, who became famous with her autobiographical work Karukku (1992). Vanmam is unique as a novel. The central focus is on caste issues and not simply on the outrage against the Dalits.

The background of Vanmam is a village in Tamil Nadu and it deals with the hostility between two castes within the Dalit community- Pallar and Parayar and also the dominant Naicker caste- the landowners mend fires in between the Pallar and Parayar castes to maintain their status.

\section{Published By:}

Blue Eyes Intelligence Engineering \& Sciences Publication (C) Copyright: All rights reserved.

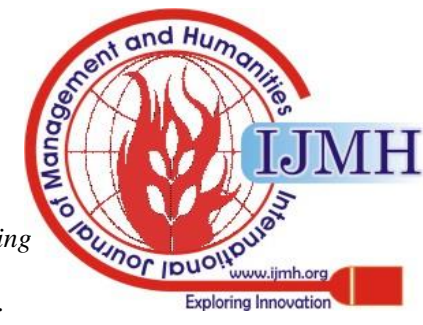


The novel takes up on an illusively calm note. The young men from the Parayar caste, Saminathan and Jayaraju, who are empowered through college education, are sensible to the rights and opportunities they have been nullified for generations and they are irritated about their backward status, in this multi-caste village in which the chavady (the meeting place), fields, orchards, the streets of the Pallars, Parayars and Naickers show the cultural diversity of various castes and their functions. The essence of the story deals with revenge and counter-revenge which ends in a caste clash. From this gory clash many young men escape, children cannot attend school, women are widowed and the children are orphaned- a picture of utter chaos and complete loss of dignity to all involved. These incidents drive home the point that it is the people from the dominant caste who are behind instigating violence among the Pallars and the Parayars. The enlightened youth help make are thinking, make way for a sinking of their differences, and unite the two sets of people.

\section{IV.PORTRAYAL OF DALIT WOMEN IN VANMAM (VENDETTA)}

Bama's novels mainly focus on the caste and gender discrimination and she portrays the caste-discrimination in Hinduism and Christianity. Bama's works are based on Dalit feminism and show the innate strength of the marginalized Dalit women. Here is a writer who considers herself a warrior and attempts to utilize her pen as a weapon to fight against the social hierarchy and the dehumanizing caste consciousness. According to Bama, the Dalit women are the victims of a double marginalization: caste and gender. Their urgent need is strong support to overcome their sufferings so that they can be strong pillars of their families and strive to uplift their society. The novel brings out how these Dalit women themselves work hard to educate their male child - but not the female child. But the female children manage to complete the education available to them in the nearby schools. Pursuing higher studies is far beyond their scope. Dalit women are portrayed as being well aware of the importance of education. One of the female characters in the novel, Mekkelamma is very eager to read her son's letter though she is an illiterate. She seeks the help of a literate neighbour to read her son's letter. Though illiterate, she eagerly works to educate her children. Quite so are several others in the community. All the women in the novel Vanmam are enthusiastic and never indolent. Like Mekkalamma's son Saminathan is sent to college, Nanamma's son Jayaraju is doing his graduation. While Therasamma urges her son complete graduation, she does not bother to do the same about her daughter Fathima. This highlights how the already marginalized Dalit women also suffer discrimination by gender.

Bama underlines how, for Dalit women there is further suffering in addition to these discriminations. They are also made to remain nondescript in matters of self identity. They cannot enter into the chavady (the meeting place of men). Though the men allow them to watch the cultural programmes, they are not to participate in them. Many are interested and even talented in dance and other art, but are discouraged by the reprimanding men.

In spite of all these setbacks we see that the Dalit women are strong both bold in nature and strong. Whenever these caste-based violence erupts, the men suddenly and invariably disappear seeking safety zones. It is the women who face the fury of the police. It is the old women, girls and children who get tortured by the police. These women are also deprived of the bare essentials like enough food and proper sleep. They cannot get medical treatment either. Not do their men help or guard the min times of need. In spite of all these adverse circumstances they are seen as mentally strong enough - they are the ones who go out to collect the injured and the dead after an incidence of violence."Though misfortunes and problems continued to pile up, the women faced them all resourcefully." [123]. (Bama, 2008)

\section{V.CONCLUSION}

In the overall space one may allot to Dalit literature, Dalit women clearly demand and deserve special respect and pride of place. They indeed form a separate class and stream as women. One can assert boldly that any discussion of Dalits, or the Dalit literature itself is bound to be incomplete without special reference to Dalit women. According to Anupama Rao in her Introduction: Caste, Gender and Indian Feminism, Dalit women are, "thrice-subjugated as women, as Dalit women, and as Dalit women who perform stigmatized labour"'(11).The assessment by Dr. B.R. Ambedkar is that the Dalit women occupy a despicably deplorable bottommost space in the social pyramids.

\section{REFERENCE}

1. Bama. Vanmam: Vendetta. Translated by Malini Seshadri, OUP, 2008.

2. Chandra, Ramesh. Phases of Dalit Revolt. New Delhi: Commonwealth Publishers, 2003.

3. Pai, Sudha. Dalit Assertion.OUP, 2013.

4. Rao, Anupama. Introduction: Caste, Gender and Indian Feminism.

New Delhi: Kali for Women \& Women Unlimited, 2003

5. Sadangi, Himansu Charan. Dalit: The Downtrodden of India.

6. ISHA Books, 2008.

\section{AUTHORS PROFILE}

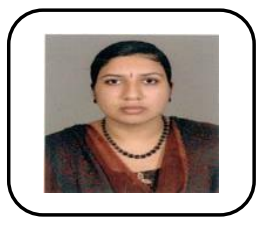

J. Rajasree Menon, is a research scholar pursuing her Ph.D in the Department of English Amrita Vishwa Vidyapeetham, Amritapuri Campus, Kollam. She obtained M.Phil degree in 2018. She has participated and presented papers at various seminars and conferences. She has published articles in national and international Journals.

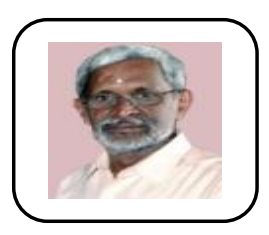

Dr. Ramanathan $\mathbf{P} \mathbf{V}$, has been working in Amrita Vishwa Vidyapeetham since 2005. He received M.Phil and Ph.D degrees from the University of Madras. His areas of interest include English Language Teaching, Literature, Religion in Literature and Religious Poetry.

He has presented several papers at national and international conferences and seminars in these areas. He is a member of the English Language Teachers' Association of India (ELTAI) and the Comparitive Literature Association of India (CLAI). 